\title{
4: 75100144-75101988
}

National Cancer Institute

\section{Source}

National Cancer Institute. 4: 75100144-75101988. NCI Thesaurus. Code C42032.

Physical location of CXCL1_Gene 